\title{
Effectiveness of winter wheat cultivation in adaptive crop rotation on chernozem typical
}

\author{
Ivan Prushchik ${ }^{1 *}$, and Svetlana Khlupina ${ }^{1}$ \\ ${ }^{1}$ FSBSI "Federal Agricultural Kursk Research Center" 70b, Karl Marx St., Kursk, 305021, Russia
}

\begin{abstract}
The paper presents the results of research to assess the efficiency of winter wheat (Triticum aestivum L.) cultivation in adaptive crop rotations on typical chernozem. The crop yield have analyzed for three different crop rotations (grain-fallow, grain-grass-row, and grain-grass) in comparison with a monoculture on a stationary multifactorial field experiment on physical modeling of the farming system of the FSBSI "Kursk FARC" (Kursk region, Medvensky district). It was determined that the maximum yield was obtained in grain-and-row crop rotation; on average, over three years of research, the increase in it was $1.71 \mathrm{t} / \mathrm{ha}$. Statistical data processing has carried out and correlations between the weather conditions of the year and the yield of winter wheat has revealed. Thus, a moderate direct relationship $(r=0.65)$ was established with atmospheric precipitation, and a moderate inverse relationship with the sum of effective temperatures $(\mathrm{r}=0.58)$. Indicators of economic efficiency of winter wheat cultivation have calculated, both for monoculture and for three types of crop rotations. The lowest cost of winter wheat grain $-5926.94 \mathrm{t} / \mathrm{ha}$ - was recorded in grain-fallow crop rotation, which provided the highest net income of 12056.26 and the highest profitability among all options $-68.72 \%$.
\end{abstract}

Keywords: winter wheat, chernozem typical, adaptive crop rotation.

\section{Introduction}

Winter wheat (Triticum aestivum L.) occupies a significant position among grain crops in Russia [1].The specific weight of winter wheat in the grain wedge is more than $50 \%$ [2].

On average, the increase in the yield of winter wheat since the beginning of the century is higher than in the United States, but is almost 2 times lower than in Canada [3].

Grain production using adaptive technologies involves the maximum use of the soil and climatic conditions of the region and the effective use of available means of production. These technologies would were aimed at obtaining a truly possible yield in specific conditions, taking into account the achievement of a profitability level of at least $10 \%[4,5]$.

In relation to crops of monoculture, in which there is no species diversity, because of which it is completely labile, the crop rotation can have taken as biodiversity, the result of which is enormous. According to foreign researchers, a sharp decrease in the yield of winter wheat has established when switching to monoculture cultivation from crop rotation $[6,7]$.

Crop rotation is possible to consider one of the most affordable and cost-effective means in the farming system [8-15]. Cultivation of winter wheat in a crop rotation makes it possible to improve the phytosanitary state in comparison with cultivation in monoculture, and, consequently, to increase productivity [16].
One of the ways to increase the yield of winter wheat is the use of adaptive crop rotations. This has confirmed by many foreign and domestic studies [5]. Adaptive crop rotation is the basis of modern cultural farming, when the natural conditions of crop cultivation in many ways contribute to the greatest return to the productivity of cultivated crops [5]. The term crop rotation refers to the scientifically based rotation of crops (and pairs) across fields and over time [17].

The generally accepted definition of crop rotation implies a scientifically grounded alternation of crops (and pairs) across fields and in time. The unifying direction of the crop rotation activity is that its positive qualities have enhanced with the manifestation of differences in the changing crops in biology and growing technology [10].

The purpose of the research is to assess the efficiency of winter wheat cultivation in adaptive crop rotations on chernozem typical.

\section{Materials and methods}

The studies have carried out on a stationary multifactorial field experiment on the physical modeling of the farming system of Federal State Scientific Institution «Federal Agricultural Kursk Research Center».

Geographical location: Kursk region, northern part of Medvensky district, Panino N 51.530; E 36.120.

Crops are located on the watershed. We sowed soft winter wheat of the Sintetik variety, recommended for cultivation in the Kursk region. Seeding rate 5.5 million pcs/ha.

\footnotetext{
*Corresponding author: kursk.iva@inbox.ru
} 
We studied the cultivation of winter wheat (Triticum aestivum L.) (cv. Synthetic) in the period from 2012 to 2020 in three types of crop rotations:

1. grain-fallow crop rotation (GF): pure steam - winter wheat (Triticum aestivum L.) - corn (Zéa máys) for green feed - spring barley (Hordeum vulgare);

2. grain-grass-row crop rotation (GGF): perennial herbs (Onobrëchis arenária) of the 1 st year of use - winter wheat (Triticum aestivum L.) - corn (Zéa máys) on green feed - spring barley (Hordeum vulgare) + perennial grasses;

3. grain-grass crop rotation (GG): perennial grasses (Onobrëchis arenária) of the 1st year of use - perennial grasses (Onobrëchis arenária) of the 2nd year of use winter wheat (Triticum aestivum L.) - spring barley (Hordeum vulgare) + perennial grasses (Onobrýchis arenária).

Perennial grasses have represented by sandy esparcete (Onobrýchis arenária).

Comparison of the yield have carried out with a monoculture of winter wheat located in the same experiment.

The main tillage is dump plowing to a depth of 20-22 $\mathrm{cm}$. Options without fertilization have considered in order excluding the influence of factors other than crop rotation.

The seeding rate of seeds is 5 million pcs/ha.

The experiment has repeated two times, the placement of variants has randomized by the method of split plots.

The area of the plots in crop rotations is $100 \mathrm{~m}^{2}$, on permanent crops $-200 \mathrm{~m}^{2}$.

The soil of the experimental site is typical, mediumthick, heavy loamy chernozem, underlain by pale-yellow medium loess-like loam.

The description of the soil section has given below.

PU (0-20) - dark gray, uniformly colored arable horizon, moist, compacted, and medium loamy. There are small roots and worms. The structure is blocky, coarsely lumpy-powdery. The transition is noticeable in density. The border is smooth.

AU (20-32) - humus horizon, dark gray, uniformly colored, There are brown spots along the paths of animals. Fresh, firm. More dense at the bottom. Heavy loamy. Coarse-lumpy-blocky structure. Roots meet. The transition is gradual, noticeable in color. The border is unclear.

$\operatorname{AUB}_{c a}(32-73(75))$ - humus horizon, dark gray with a brownish tint, unevenly colored, moist, compacted, heavy loamy. The structure is lumpy-nutty-powdery. Moleholes have found in the lower part. The boiling depth coincides with the lower part of the horizon. molehills filled with dark material. The boiling depth coincides with the lower part of the horizon $(70 \mathrm{~cm})$. The transition is gradual, noticeable in color. The border is uneven, lingual.

$\mathrm{B}_{\mathrm{ca}}$ (75-105) - transitional carbonate horizon, brownish-fawn, humid, compacted, heavy loamy. The structure is prismatic. It has dark humus narrow tongues, streaks. There are inclusions of calcium carbonate. At a distance of 80-85 $\mathrm{cm}$ from the surface, a molehill filled with dark soil. Presence of carbonate powder. The transition is gradual, noticeable in color. The border is uneven, lingual.
$\mathrm{C}_{\mathrm{ca}}(105-)$ - pale-yellow carbonate horizon, moist, compacted, loamy. Structureless. There are inclusions of calcium carbonate.

Humidity and productive moisture reserves were determined according to A.F. Vadyunina, Z.A. Korchagina, 1986 [12] GOST 28268-89.

Accounting for the yield of winter wheat have carried out by the method of direct mechanized harvesting with recalculation of $100 \%$ purity and $14 \%$ moisture (GOST 27548-97). The data has processed by the method of dispersion and correlation analyzes [19].

Calculations of the economic efficiency of winter wheat cultivation in various crop rotations had carried out based on technological maps of prices for 2020 .

\section{Results and Discussion}

In general, the climatic conditions of the Central Chernozem Region make it possible to obtain a high yield of winter wheat grain annually. However, the provision of stable crop yields in some years can be constrained by the lack of precipitation, available moisture in the soil and the influence of high air temperatures [14]. During the observation period, the sum of effective temperatures for the spring-summer period (March-July) in 2012 amounted to $2133.9^{\circ} \mathrm{C}$, in $2016-1989.3^{\circ} \mathrm{C}$, and in $2020-1841.4$ ${ }^{\circ} \mathrm{C}$ with a norm of $1809.9^{\circ} \mathrm{C}$ (fig. 1).

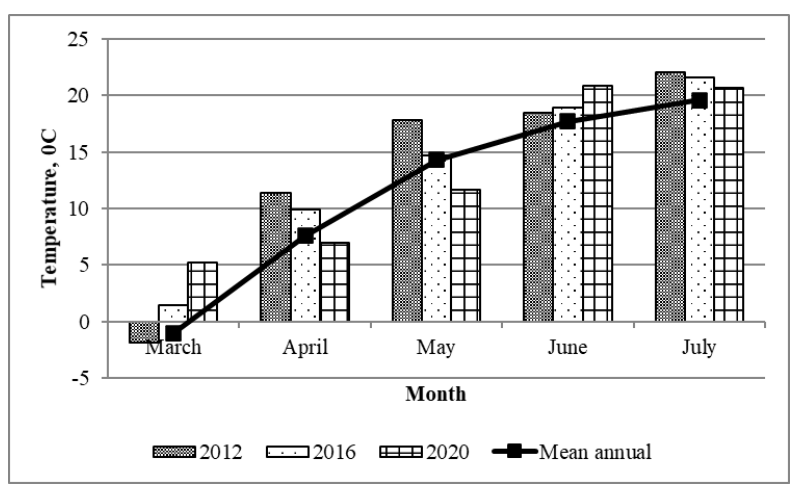

Fig. 1. Average monthly air temperature for 2012-2020

Sufficient moisture supply during the regrowth and tillering of plants in the spring has determined by both the presence of free soil moisture and the prevailing weather conditions. The content of productive moisture in the soil layer is of great importance for the sowing of winter wheat. During the years of research, they differed significantly in the amount for precipitation.

The peak of moisture consumption from the soil falls on the phase of intensive growth of the stem; therefore, precipitation is shown from March, and not from September (sowing of the crop). Those from the spring renewal of vegetation, and not from the sowing of the culture. Thus, from March to July, over the years of research, 284.0 fell; $442.0 ; 322.0 \mathrm{~mm}$, which respectively amounted to $98.61 ; 153.5$ and $111.8 \%$ relative to the average long-term data (Fig. 2). 


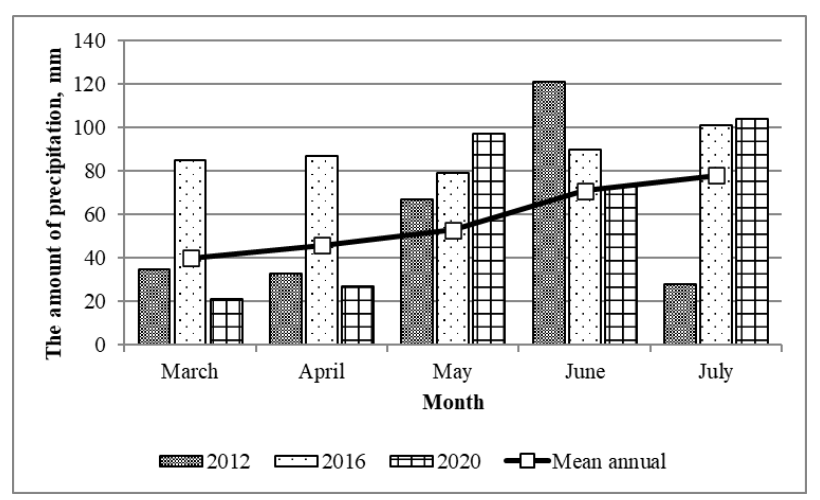

Fig. 2. The amount of precipitation by months for 2012-2020

Observations of the water regime of the soil showed that the reserves of productive moisture over the years of research in the studied crop rotations were unevenly distributed. So, in 2012, the maximum content of available moisture in a meter layer of soil has noted in the grain-herb crop rotation $-242.0 \mathrm{~mm}$, and in 2016 and 2020 in the grain-fallow crop rotation -205.3 and 251.2 $\mathrm{mm}$, respectively. The minimum moisture reserve in 2012 and 2020 fixed in grain-grass cultivation - $180.0 \mathrm{~mm}$; $188.2 \mathrm{~mm}$, and in 2016 - in grain-grass crop rotations.

In general, according to the assessment of productive moisture reserves according to A.F. Vadyunina and Z.A. Korchagina [12], in all variants of studies at the beginning of the renewal of the spring vegetation of winter wheat, the content of productive moisture in the arable soil layer was sufficient $(>40 \mathrm{~mm})$ and had the same direction from grain-grass cultivation to grain-fallow crop rotation in the direction of its increase as the moisture content in meter layer of soil according to crop rotation.

In permanent crops of winter wheat, the content of productive moisture was lower in all years of research, in comparison with crop rotations.

According to the results of our research, a correlation was established between the yield and meteorological conditions of the year of winter wheat cultivation, with precipitation - a moderate straight line $(r=0.65)$, with the sum of effective temperatures - a moderate inverse $(\mathrm{r}=$ $0.58)$.

So, in 2012, characterized by the highest number of temperatures and the minimum amount of precipitation, the lowest yield of winter wheat was obtained for all options, the average yield according to the experience was $1.62 \mathrm{t} / \mathrm{ha}$.

The most productive year in terms of gross grain harvest was 2016, the most moisture-rich in terms of the received atmospheric precipitation and a comfortable medium-moderate in temperature regime. In the same year, the highest yield increase has obtained in the graingrass-row crop rotation, where pure fallow was the predecessor of winter wheat. The reserve of productive moisture in the arable layer of this crop rotation was the largest of all the experimental options over the years of research, amounting to $56.6 \mathrm{~mm}$.

The productivity of the crop in 2020 was intermediate, with an average of $2.58 \mathrm{t} / \mathrm{ha}$ for all variants of the experiment.
Analysis of the experimental data obtained shows that the increase in yield in the context of the studied crop rotations occurred from grain-grass to grain-grass-row crop rotation, providing it with a maximum yield increase of $1.71 \mathrm{t} /$ ha (Table 1$)$.

Table 1. The influence of crop rotations on the yield of winter wheat (average over 3 years)

\begin{tabular}{|c|c|c|c|c|c|}
\hline \multirow{2}{*}{ Variant } & \multicolumn{4}{|c|}{ The yield, $t / h a$} & \multirow{2}{*}{$\begin{array}{l}\text { Increase } \\
+/ \text { - t/ha }\end{array}$} \\
\hline & 2012 & 2016 & 2020 & $\begin{array}{l}\text { Ave } \\
\text { rage }\end{array}$ & \\
\hline $\begin{array}{l}\text { The } \\
\text { monoculture }\end{array}$ & 1.12 & 1.25 & 1.39 & 1.25 & - \\
\hline GF & 1.72 & 4.07 & 3.09 & 2.96 & +1.71 \\
\hline GGR & 1.88 & 3.10 & 2.90 & 2.63 & +1.38 \\
\hline GG & 1.75 & 2.74 & 2.92 & 2.74 & +1.22 \\
\hline NSR 05 & \multicolumn{5}{|c|}{0.96} \\
\hline
\end{tabular}

From the data in Table 1, it follows that all average annual yield values for all crop rotations and monocultures are reliable (their relative error is less than $100 \%$ ). For all rotations and monocultures, the relative error for the average yield is small.

In the same grain-grass-row crop rotation in 2016, the maximum yield of winter wheat has obtained $-4.07 \mathrm{t} / \mathrm{ha}$, which was 1.4 times higher than the average long-term values of crop yield in this long-term experience [16].

Analysis of the data showed that the values of the yield of winter wheat are reliable for all variants of the experiment $(\mathrm{NSR}=0.96)$.

For an objective assessment of the studied crop rotations, the indicators of the economic efficiency of winter wheat cultivation were calculated (Table 2).

Table 2. Efficiency of winter wheat cultivation depending on crop rotations (average over 3 years)

\begin{tabular}{|c|c|c|c|c|}
\hline Indicators & $\begin{array}{l}\text { The } \\
\text { monocul } \\
\text { ture }\end{array}$ & GF & GGR & GG \\
\hline Yield, t/ha & $\begin{array}{l}1.25 \pm 0.1 \\
3\end{array}$ & $\begin{array}{l}2.96 \pm 1.1 \\
8\end{array}$ & $\begin{array}{l}2.63 \pm 0.6 \\
5\end{array}$ & $\begin{array}{l}2.74 \pm 0.6 \\
3\end{array}$ \\
\hline $\begin{array}{l}\text { Production } \\
\text { costs, RUB } \\
\text { /ha }\end{array}$ & $\begin{array}{l}16560.2 \\
5\end{array}$ & 17543.74 & 15765.26 & 16636.66 \\
\hline $\begin{array}{l}\text { Cost of } 1 \text { ton } \\
\text { of grain, } \\
\text { RUB. }\end{array}$ & $\begin{array}{l}13248.2 \\
0\end{array}$ & 5926.94 & 5994.39 & 6071.77 \\
\hline $\begin{array}{l}\text { Net income, } \\
\text { RUB/ha }\end{array}$ & -4060.25 & 12056.26 & 10534.74 & 10763.34 \\
\hline
\end{tabular}

The analysis of economic efficiency showed that the production costs for grain-fallow crop rotation were the highest 1753.74 rubles/ha.

The lowest costs have observed in the cultivation of winter crops after perennial grasses of the 1st year of use in grain-and-grass crop rotation - $15765.26 \mathrm{rubles} / \mathrm{ha}$, in the same variant one of the lowest cost of one ton of grain - 5994.39 rubles. 
This is due to the lowest cost compared to other predecessors.

The lowest cost of grain, $5926.94 \mathrm{t} / \mathrm{ha}$, was in the grain-grass-row crop rotation; its decrease led to an increase in the profitability of this option $-68.72 \%$.

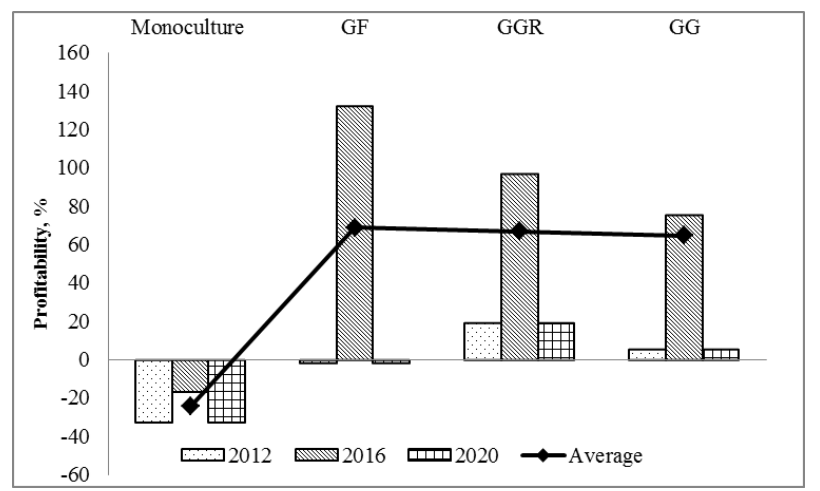

Fig. 3. Profitability of winter wheat cultivation by years.

On the same option, the highest net income has obtained, which shows the receipt of additional cash on the farm, it amounted to 12056.26 rubles/ha.

Sufficiently good financial results were obtained in the cultivation of winter crops on perennial grasses of the 1st and 2nd years of use in grain-grass cultivation and graingrass crop rotations, where the net income amounted to 10534.74 and 10763.34 rubles/ha with a profitability of 66.82 and $64.70 \%$, respectively.

When comparing profitability between years, we found that the most efficient cultivation of winter wheat in economic terms was in 2016 (Fig. 3).

According to the analysis of economic indicators, the option of growing winter wheat in monoculture did not give a net income and, as a result, brought losses to production.

\section{Conclusion}

During the research period, it has found that the highest effect from crop cultivation has achieved in crop rotation.

At the same time, of all those studied by us, the best grain yield $-4.07 \mathrm{t} / \mathrm{ha}$, has obtained in grain-fallow crop rotation, where the precursor of winter wheat is pure fallow.

It has confirmed by the economic indicators of assessing the cultivation of winter wheat in this crop rotation, the net income is 12056.26 rubles $/$ ha, the profitability of production is $68.72 \%$. The assessment of the cultivation of winter wheat reliably showed the highest efficiency for grain-fallow crop rotation.

The authors are grateful for scientific advice to the head of the laboratory of I.I. Gureev, senior researcher L.B. Nitchenko, and as the staff of the Adaptive technologies and means of their mechanization.

The work was carried out within the framework of the Statetasks of FSBSI «Federal Agricultural Kursk Research Center» on topic No. 0632-2019-0015

\section{References}

1. N.Y. Rebouh, P.M. Polityko, E. Pakina, V.G. Plushikov, A. Norezzine, A. Gadzhikurbanov, V. Vvedenskiy, F. Duksi \& M. Iguer-ouada, Res. on Crops 20(1), 161-168 (2019)

2. W.M. Achten, A.K. Van, J. of Industrial Ecology, 20: 132-144 (2016)

3. F. Schierhorn, D. Müller, A. Prishchepov, M. Faramarzi, A. Balmann, Global Food Security 3, 3 (2014)

4. E. Lioubimtseva, K.M. de Beurs, G.M. Henebry, Climate Change and Water Resources The Handbook of Environmental Chemistry 25 (Springer, Berlin, Heidelberg, (2013)

5. A. Gostev, A. Pykhtin, S. Tarasov, BIO Web Conf. 17, $00002(2020)$

6. A.A. Iminov, F.B. Namozov, I.T. Turaevich, Actual problems of modern science, 2, 60 (2020)

7. H.M. Yuan, F.G. Zhang, D.J.P. Fan, S. Chen, X.L. Wang, J.C. Sun \& Z.J. Liu, Wheat in a Global Environment. Developments in Plant Breeding, 9 (Springer, Dordrecht. 2001)

8. Babulicová M., Plant Soil \& Environment 60(7), 297 302 (2014)

9. Fowler D.B., Duggan B., Boychuk L., Moats L. Crop Rotation for Successful Winter Wheat Production, Soils and Crops Workshop Proceedings University of Saskatchewan, SK, Feb 22-23, Saskatoon (2001)

10. M. Darguza, Z. Gaile, Research for rural development 35, 14 (2020)

11. N.A. Morozov, A.I. Khripunov, E.N. Obshchiya, Izv. Gorskogo GAU, 56(2), 32 (2019)

12. A. Wozniak, Int. J. Plant Prod. 13 (3), 177-182 (2019)

13. D.V. Dubovik, Yu.P. Sukhanovsky, L.B. Nitchenko, A.V. Pruschik, Dostiz. nauki i tekhn. APK 33(8), 5 (2019)

14. A.J. Schlegel, Y. Assefa, L.A. Haag, C.R. Thompson, L. Stone, Agron. J. 110(1), 269 (2017)

15. X. Chen, W. Zhang, X. Wang, Y. Liu, B. Yu, X. Chen, C. Zou, Science of The Total Envir. 783 (2021)

16. C.A. Deutsch, J.J. Tewksbury, M. Tigchelaar, D.S. Battisti, S.C. Merrill, R.B. Huey, R.L. Naylor, Science 361(6405), 916 (2018)

17. I.I. Gureev, Zemled. 1, 30 (2020)

18. A.F.Vadyunina, Z.A. Korchagina, Methods of research of physical properties of soils (M., Agropromizdat, 1986)

19. B.A. Dospekhov, Methods of experimental work (M., Agropromizdat, 1985)

20. Z. Meisam, N. Rebouh, E. Pakina, A. Gadzhikurbanov, M. Lyashko, B. Ortskhanov, Res. on Crops 18 (4), 575 (2017)

21. A.I. Grabovets, K.N. Biryukov, M.A. Fomenko, Zemled. 7, 25 (2020) 